\title{
Connexin-Mediated Signaling in Nonsensory Cells Is Crucial for the Development of Sensory Inner Hair Cells in the Mouse Cochlea
}

\author{
Stuart L. Johnson, ${ }^{1 *}{ }^{-}$Federico Ceriani, ${ }^{2,3,4 *}$ Oliver Houston, ${ }^{1}$ Roman Polishchuk, ${ }^{5}$ Elena Polishchuk, ${ }^{5}$

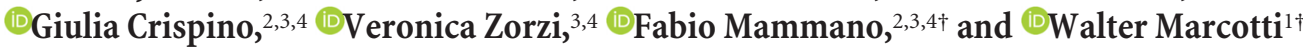 \\ ${ }^{1}$ Department of Biomedical Science, University of Sheffield, S10 2TN Sheffield, United Kingdom, 2Department of Physics and Astronomy "G. Galilei," \\ University of Padua, 35131 Padua, Italy, ${ }^{3}$ Venetian Institute of Molecular Medicine, Foundation for Advanced Biomedical Research, 35129 Padua, Italy, \\ ${ }^{4}$ Department of Biomedical Sciences, Institute of Cell Biology and Neurobiology, Italian National Research Council, 00015 Monterotondo, Italy, and \\ ${ }^{5}$ Telethon Institute of Genetics and Medicine, Pozzuoli, 80131 Napoli, Italy
}

Mutations in the genes encoding for gap junction proteins connexin 26(Cx26) and connexin $30(\mathrm{Cx} 30)$ have been linked to syndromic and nonsyndromic hearing loss in mice and humans. The release of ATP from connexin hemichannels in cochlear nonsensory cells has been proposed to be the main trigger for action potential activity in immature sensory inner hair cells (IHCs), which is crucial for the refinement of the developing auditory circuitry. Using connexin knock-out mice, we show that IHCs fire spontaneous action potentials even in the absence of ATP-dependent intercellular $\mathrm{Ca}^{2+}$ signaling in the nonsensory cells. However, this signaling from nonsensory cells was able to increase the intrinsic IHC firing frequency. We also found that connexin expression is key to IHC functional maturation. In Cx26 conditional knock-out mice $\left(C x 26^{\text {Sox10-Cre }}\right)$, the maturation of IHCs, which normally occurs at approximately postnatal day 12 , was partially prevented. Although $\mathrm{Cx} 30$ has been shown not to be required for hearing in young adult mice, IHCs from Cx30 knock-out mice exhibited a comprehensive brake in their development, such that their basolateral membrane currents and synaptic machinery retain a prehearing phenotype. We propose that IHC functional differentiation into mature sensory receptors is initiated in the prehearing cochlea provided that the expression of either connexin reaches a threshold level. As such, connexins regulate one of the most crucial functional refinements in the mammalian cochlea, the disruption of which contributes to the deafness phenotype observed in mice and DFNB1 patients.

Key words: cochlea; connexin; deafness; development; gap-junction; inner hair cells

\section{Significance Statement}

The correct development and function of the mammalian cochlea relies not only on the sensory hair cells, but also on the surrounding nonsensory cells. Although the nonsensory cells have been largely implicated in the general homeostasis in the mature cochlea, their involvement in the initial functional differentiation of the sensory inner hair cells is less clear. Using mutant mouse models for the most common form of congenital deafness in humans, which are knock-outs for the gap-junction channels connexin 26 and connexin 30 genes, we show that defects in nonsensory cells prevented the functional maturation of inner hair cells. In connexin knock-outs, inner hair cells remained stuck at a prehearing stage of development and, as such, are unable to process sound information.

\section{Introduction}

In mammals, the sense of hearing relies on mechanoelectrical transduction performed by the primary sensory receptor inner hair cells (IHCs) and the outer hair cells (OHCs). Functionally mature IHCs relay sound information to Type I spiral ganglion neurons with high temporal precision via the graded release of 
glutamate from their ribbon synapses (Fuchs, 2005). Before the onset of hearing, which in most rodents occurs at approximately postnatal day 12 , spontaneous $\mathrm{Ca}^{2+}$ action potential (AP) activity in IHCs plays a role in driving the refinement of the immature auditory circuitry (Johnson et al., 2011, 2013; Clause et al., 2014). These sensory hair cells are embedded in a matrix of epithelial nonsensory cells, which are crucial for normal cochlear function (Monzack and Cunningham, 2013). Nonsensory cells in the mammalian cochlea are interconnected by a network of gap junction channels, which are intercellular conduits formed by the head-to-head docking of two hemichannels from adjacent cells (Goodenough and Paul, 2009) creating an extensive functional syncytium in the cochlear sensory epithelium (Kikuchi et al., 1995). Gap junction channels in the mammalian cochlea are primarily formed by Cx26 and Cx30 (Ahmad et al., 2003) and mutations of the genes encoding for these two proteins ( $G j b 2$ and Gjb6, respectively) are associated with the most common form of prelingual congenital hearing impairment in humans (DFNB1) (Xu and Nicholson, 2013). Classically, the connexin-based gap junction network in the adult cochlea is thought to contribute to cochlear homeostasis (Zdebik et al., 2009). Mouse models confirmed that $\mathrm{Cx} 26$ and $\mathrm{C} \times 30$ are involved in a wide range of activities important for the normal function of the developing and mature hearing system (Mammano, 2013; Jagger and Forge, 2015; Kelly et al., 2015; Wingard and Zhao, 2015; Zhu et al., 2015).

Connexin hemichannels are known to mediate paracrine signaling by opening in response to a rise in the cytosolic free $\mathrm{Ca}^{2+}$ concentration $\left(\left[\mathrm{Ca}^{2+}\right]_{\mathrm{c}}\right)$ (Leybaert et al., 2003; De Vuyst et al., 2006). The opening of hemichannels releases intracellular ATP into the extracellular milieu, which promotes signal encoding by $\left[\mathrm{Ca}^{2+}\right]_{\mathrm{c}}$ oscillations (Uhlen and Fritz, 2010; Parekh, 2011) and conveys crucial biochemical information throughout the cochlear sensory epithelium via intercellular $\mathrm{Ca}^{2+}$ waves (Leybaert and Sanderson, 2012; Mammano, 2013). In the immature mouse cochlea, ATP-induced signaling from connexin extrajunctional hemichannels (Anselmi et al., 2008; Majumder et al., 2010) has been proposed to induce $\mathrm{Ca}^{2+}$-dependent AP activity in sensory IHCs both directly (Tritsch et al., 2007) and indirectly (Wang et al., 2015), although a more modulatory role for ATP on IHC firing has also been shown (Johnson et al., 2011). Despite the involvement of $\mathrm{Cx} 26$ and $\mathrm{Cx} 30$ in cochlear function and hearing, their exact role and the relative contribution of the two connexins to mammalian cochlear physiology during prehearing stages of development are still unclear (Liu et al., 2016).

In this study, we used three different mouse models of connexin deficiency to provide evidence for a direct role of connexins in the functional maturation of prehearing mouse IHCs. Our results indicate that ATP-induced signaling in cochlear nonsensory cells is not required for generating APs in prehearing IHCs. However, this ATP-dependent signaling increases the frequency

This article is freely available online through the J Neurosci Author Open Choice option.

Correspondence should be addressed to either of the following: Dr. Walter Marcotti, Department of Biomedical Science, University of Sheffield, S10 2TN Sheffield, United Kingdom, E-mail:w.marcotti@sheffield.ac.uk; or Dr. Fabio Mammano, Department of Biomedical Sciences, Institute of Cell Biology and Neurobiology, Italian National Research Council, 00015 Monterotondo, Italy. E-mail: fabio.mammano@cnr.it.

F. Ceriani's current address: Department of Biomedical Science, University of Sheffield, Sheffield, United Kingdom.

DOI:10.1523/JNEUROSCI.2251-16.2016

Copyright $\odot 2017$ Johnson, Ceriani et al.

This is an Open Access article distributed under the terms of the Creative Commons Attribution License Creative Commons Attribution 4.0 International, which permits unrestricted use, distribution and reproduction in any medium provided that the original work is properly attributed. of the intrinsically generated AP activity in IHCs. We also found that a threshold level for the expression of both $\mathrm{Cx} 26$ and $\mathrm{C} \times 30$ is required for the acquisition of the mature sensory profile in IHCs.

\section{Materials and Methods}

Ethics statement. In the United Kingdom, experiments were performed in accordance with Home Office regulations under the Animals (Scientific Procedures Act) 1986 and following approval by the University of Sheffield Ethical Review Committee. In Italy, animal work was approved by the Ethics committee of the University of Padua (Protocol 104230, October 12, 2013).

Tissue preparation. Apical coil IHCs from transgenic mice of either sex (Cx30(-/-) (MGI:2447863): Teubner et al., 2003; Cx30 $0^{\Delta / \Delta}$ (MGI: 5486677): Boulay et al., 2013; Cx26 ${ }^{\text {Sox10Cre }}$ : Anselmi et al., 2008; Crispino et al., 2011) and their littermate controls were studied in acutely dissected organs of Corti from postnatal day 3 (P3) to P25, where the day of birth is P0. Targeted ablation of Cx26 in the nonsensory cells was achieved by crossing Cx26 ${ }^{\text {loxP/loxP }}$ (MGI:2183509) (Cohen-Salmon et al., 2002) mice with Sox10-Cre mice (MGI:3586900) (Matsuoka et al., 2005). Sox10 is predominantly expressed in glial cells of the nervous system (Kuhlbrodt et al., 1998), and in the cochlea it is found in the nonsensory cells of the greater epithelial ridge (GER, also known as Kölliker's organ) and in other supporting cells of the organ of Corti surrounding the IHCs and OHCs, but not in IHCs or OHCs (Watanabe et al., 2000). Genotyping protocols were performed by PCR using the primers previously described (Anselmi et al., 2008; Boulay et al., 2013). After killing the animals by cervical dislocation, cochleae were rapidly dissected (Marcotti et al., 2003) and kept in the following extracellular solution (in mM): $135 \mathrm{NaCl}$, $5.8 \mathrm{KCl}, 1.3 \mathrm{CaCl}_{2}, 0.9 \mathrm{MgCl}_{2}, 0.7 \mathrm{NaH}_{2} \mathrm{PO}_{4}$, 5.6 D-glucose, 10 HEPES$\mathrm{NaOH}, 2$ sodium pyruvate; MEM amino acids solution $(50 \times$, without L-glutamine) and MEM vitamins solution (100X) were added from concentrates (Fisher Scientific); $\mathrm{pH}$ was adjusted to 7.5, $\sim 308 \mathrm{mOsmol}$ $\mathrm{kg}^{-1}$. Dissected cochleae were transferred to a microscope chamber, immobilized using a nylon mesh fixed to a stainless steel ring, and continuously perfused with the above extracellular solution. The sensory epithelia were viewed using an upright microscope (Leica, Olympus) with Nomarski differential interference contrast optics $(63 \times$ waterimmersion objectives and $10 \times$ or $15 \times$ eyepieces). All recordings were performed near body temperature $\left(34^{\circ} \mathrm{C}-37^{\circ} \mathrm{C}\right)$ unless otherwise stated.

Whole-cell patch clamp. Voltage and current recordings were performed using Axopatch 200B (Molecular Devices), EPC7 (HEKA), and Optopatch (Cairn Research) amplifiers. Patch pipettes, with resistances of $2-4 \mathrm{M} \Omega$, were pulled from soda glass capillaries, and the shank of the electrode was coated with surf wax (Mr Zoggs Sex Wax). For current and voltage recordings, the pipette intracellular solution contained the following (in $\mathrm{mM}$ ): $131 \mathrm{KCl}, 3$ $\mathrm{MgCl}_{2}$, 1 EGTA-KOH, $5 \mathrm{Na}_{2}$ ATP, 5 HEPES-KOH, 10 sodium phosphocreatine, $\mathrm{pH}$ 7.3; for cell-attached recordings, the pipette contained the following (in mM): $140 \mathrm{NaCl}, 5.8 \mathrm{KCl}, 1.3 \mathrm{CaCl}_{2}, 0.9 \mathrm{MgCl}_{2}, 0.7 \mathrm{NaH}_{2} \mathrm{PO}_{4}, 5.6$ D-glucose, 10 HEPES-NaOH, pH 7.5.

Exocytosis was measured using the following intracellular solution (in mM): 106 Cs-glutamate, $20 \mathrm{CsCl}, 3 \mathrm{MgCl}_{2}$, 1 EGTA-CsOH, $5 \mathrm{Na}_{2} \mathrm{ATP}$, $0.3 \mathrm{Na}_{2} \mathrm{GTP}, 5$ HEPES-CsOH, $10 \mathrm{Na}_{2}$-phosphocreatine, pH 7.3. Data acquisition was controlled by pClamp software (RRID:SCR_011323) using Digidata 1320A or 1440A boards (Molecular Devices). Recordings were low-pass filtered at $2.5 \mathrm{kHz}$ (8-pole Bessel) and sampled at $5 \mathrm{kHz}$ and stored on computer for off-line analysis (Origin: OriginLab, RRID: SCR_002815).

Membrane potentials were corrected for the voltage drop due to the series resistance $R_{\mathrm{s}}(2.7 \pm 0.2 \mathrm{M} \Omega, n=98)$ and liquid junction potential $\left(\mathrm{K}^{+}\right.$- and $\mathrm{Cs}^{+}$-based intracellular solution: $-4 \mathrm{mV}$ and $-11 \mathrm{mV}$, respectively). The Mini Analysis Program (RRID:SCR_002184: Synaptosoft) was used to detect spike events in cell-attached recordings. The AP frequency in Figure 1 was calculated as the reciprocal of the mean interspike interval for each cell and an indication of the spread of interspike interval values about the mean was obtained by calculating the coefficient of variation, equal to the SD divided by the mean. The firing rates in Figure 2 were estimated by convolving spike trains with a Gaussian kernel (SD 1 s) (Cunningham et al., 2009). 
Statistical analysis. Statistical comparisons of means were made by Student's two-tailed $t$ test. Mean \pm SEM values are reported; $p<0.05$ indicates statistical significance.

Calcium dye loading in cochlear preparations. For calcium dye loading, acutely dissected preparations were incubated for $40 \mathrm{~min}$ at $37^{\circ} \mathrm{C}$ in DMEM/F12, supplemented with fluo-4 AM (final concentration 16 $\mu \mathrm{M}$; Thermo Fisher Scientific). The incubation medium contained also pluronic F-127 (0.1\%, w/v, Sigma-Aldrich), and sulfinpyrazone $(250 \mu \mathrm{M})$ to prevent dye sequestration and secretion. Preparations were then transferred to the microscope stage and perfused with extracellular solution for $20 \mathrm{~min}$ to allow for deesterification before initiating image acquisition.

Confocal $\mathrm{Ca}^{2+}$ imaging. $\mathrm{Ca}^{2+}$ signals were recorded using a custombuilt spinning disk confocal microscope (Ceriani et al., 2016a). Fluorescence excitation was produced by light emitted from a $470 \mathrm{~nm}$ LED (M470L2, Thorlabs) filtered through a BP460-480 filter (Olympus), and directed onto the sample through a 515 DCXR dichromatic mirror (Chroma Technology). Fluo-4 emission was filtered through a 535/43M bandpass interference filter (Edmund Optics). Confocal fluorescence images were formed by a water-immersion objective $(40 \times \mathrm{NA} 0.8$, Olympus) and projected onto a scientific-grade camera (PCO Edge; PCO AG) controlled by software developed in the laboratory. Image sequences of Fluo-4 fluorescence were acquired continuously at 10 frames per second with $100 \mathrm{~ms}$ exposure time. To synchronize image acquisition and electrical recordings, we sampled the $5 \mathrm{~V}$ pulse that signals active exposure of the camera. $\mathrm{Ca}^{2+}$ signals were measured as relative changes of fluorescence emission intensity $\left(\Delta F / F_{0}\right) . \Delta F=F-F_{0}$, where $F$ is fluorescence at time $t$ and $F_{0}$ is the fluorescence at the onset of the recording; $F_{0}$ was comparable among the five different cochlear preparations used for these experiments (see Results).

Transmission electron microscopy. For transmission electron microscopy, cochleae dissected from 4-week-old mice were prepared as previously described (Mahendrasingam et al., 2011). Briefly, cochleae were fixed by perfusion with $2.5 \%$ glutaraldehyde in 0.1 M sodium cacodylate buffer containing $2 \mathrm{~mm}$ calcium chloride, $\mathrm{pH} 7.4$, and immersed in the same fixative for $2 \mathrm{~h}$. Cochleae were then washed in $0.1 \mathrm{M}$ sodium cacodylate buffer containing 2 mu calcium chloride, $\mathrm{pH} 7.4$, fixed in $1 \%$ osmium tetroxide in the same buffer for $1 \mathrm{~h}$ and decalcified in $5.5 \%$ EDTA/0.1\% PFA solution for $3-4 \mathrm{~d}$ at $4^{\circ} \mathrm{C}$. Decalcified cochleae were sectioned into $100-\mu \mathrm{m}$-thick slices, using a vibratome (Leica) equipped with a Gillette Platinum blade, and postfixed in uranyl acetate and in $\mathrm{OsO}_{4}$. After dehydration through a graded series of ethanol, the samples were cleared in propylene oxide, embedded in the Epoxy resin (Epon 812 ), and polymerized at $60^{\circ} \mathrm{C}$ for $72 \mathrm{~h}$. From each embedded vibratome slice, $65 \mathrm{~nm}$ thin serial sections were cut in the region of interest using Leica EM UC7 ultramicrotome (Leica Microsystems) and collected on formvar-carbon coated slots. EM images of inner hair cells and ribbon synapses were acquired from thin serial sections using a FEI Tecnai-12 electron microscope (FEI) equipped with a VELETTA CCD digital camera (Soft Imaging Systems). Quantification of the number of synapseassociated vesicles was performed using the iTEM software (Soft Imaging Systems).

\section{Results}

\section{AP activity in IHCs is normal in the absence of connexins 30} and 26

Spontaneous $\mathrm{Ca}^{2+}$-dependent AP activity occurs in IHCs of the mammalian cochlea during prehearing stages (Glowatzki and Fuchs, 2000; Beutner and Moser, 2001; Marcotti et al., 2003; Johnson et al., 2011, 2012). The frequency of these APs has been shown to be directly modulated not only by the efferent neurotransmitter ACh (Glowatzki and Fuchs, 2000), but also by the release of ATP from nonsensory cells in the GER (also known as Kölliker's organ) (Johnson et al., 2011). Recent studies have challenged this view and have proposed that AP activity in IHCs is not spontaneous but is instead triggered by $\mathrm{Ca}^{2+}$ waves (Tritsch et al., 2007, 2010; Wang et al., 2015) mediated by the release of ATP from connexin hemichannels (Anselmi et al., 2008; Majumder et al., 2010; Schütz et al., 2010; Rodriguez et al., 2012; Ceriani et al., 2016b). To address this controversial issue, we investigated AP activity in immature IHCs using connexin knock-out mice. To approach normal physiological recording conditions as best as possible, we performed experiments at body temperature $\left(34^{\circ} \mathrm{C}-\right.$ $37^{\circ} \mathrm{C}$ ), using $1.3 \mathrm{mM} \mathrm{Ca}^{2+}$ and $5.8 \mathrm{mM} \mathrm{K}^{+}$in the extracellular solution, which mimics the perilymph surrounding the basolateral pole of hair cells (Wangemann and Schacht, 1996). For whole-cell recordings, $1 \mathrm{~mm}$ EGTA was used as the intracellular calcium buffer, which was previously assessed using perforated patch recordings where the mobile endogenous $\mathrm{Ca}^{2+}$ buffer is retained in the cell (Johnson et al., 2008).

We initially used $C x 30(-/-)$ mice (Teubner et al., 2003) in which the mRNA and protein expression of Cx30 is abolished and, during prehearing stages, those of $\mathrm{Cx} 26$ are also reduced to only $\sim 10 \%$ of that present in wild-type mice (Ortolano et al., 2008; Boulay et al., 2013). In these $C \times 30(-/-)$ mice, the occurrence of spontaneous ATP-induced $\mathrm{Ca}^{2+}$ wave events in the GER is largely reduced (Rodriguez et al., 2012). Therefore, if the AP activity in IHCs were solely dependent on ATP-induced signaling from the nonsensory cells (Tritsch et al., 2007; Wang et al., 2015), it should be either absent or strongly reduced in these $C \times 30(-/-)$ mice. However, using either whole-cell current clamp (Fig. 1A) or cell-attached voltage clamp (Fig. 1B), we recorded spontaneous APs in IHCs from both wild-type and littermate P3-P4 Cx30(-/-) mice. In the cell-attached condition, APs take the form of capacitative currents that are abolished when IHCs are superfused with a $\mathrm{Ca}^{2+}$-free solution (Johnson et al., 2011). Long-lasting cell-attached recordings allowed us to investigate whether the firing pattern of APs in IHCs was affected by the genetic ablation of connexins in nonsensory cells. We used the coefficient of variation as a quantitative measure of regularity in spontaneous spike firing and found that in IHCs from wild-type (control) mice (3.26 \pm $0.25, \mathrm{P} 4, n=7)$ it was similar to that measured in cells from $C \times 30(-/-)$ littermates $(2.83 \pm 0.26, \mathrm{P} 4, n=9 . p=0.3)$ (Fig. $1 C)$. We also found that the resting membrane potentials and the size of immature $\mathrm{K}^{+}$currents (Fig. $1 D$ and Fig. $1 E$, respectively; Table 1) from control IHCs were similar to those of Cx30(-/-) littermates.

To confirm that $\mathrm{Ca}^{2+}$ waves are not required for AP activity in IHCs, we combined $\mathrm{Ca}^{2+}$ imaging from the GER (Majumder et al., 2010; Rodriguez et al., 2012) with cell-attached patch-clamp recordings from single IHCs (Johnson et al., 2011). Acutely dissected cochleae from $C \times 30(-/-)$ mice $(n=5)$ were loaded with the $\mathrm{Ca}^{2+}$ indicator Fluo-4 before starting electrophysiological recordings. We found that spontaneous AP activity was present in IHCs, even in the absence of detectable $\mathrm{Ca}^{2+}$ signals in the surrounding nonsensory cells (Fig. $2 A, C$ ). These results indicate that the origin of IHC electrical activity is independent from ATP-induced $\mathrm{Ca}^{2+}$ waves from nonsensory cells. In recordings where some $\mathrm{Ca}^{2+}$ signals remained in the nonsensory cells of the GER of $C \times 30(-/-)$ mice, likely due to the residual expression of Cx26, the intrinsic AP activity of the patched IHC showed a rapid and transient increase in its firing frequency, which was correlated with the $\mathrm{Ca}^{2+}$ wave (Fig. $2 \mathrm{~B}, D$ ). Also, at the beginning of the recordings in Figure $2 B, D$, the IHC fired APs, even in the absence of $\mathrm{Ca}^{2+}$ signals from nonsensory cells. This adds further support to the above findings showing that $\mathrm{AP}$ activity is intrinsic to IHCs and is extracellularly modulated by ATP-dependent $\mathrm{Ca}^{2+}$ waves in cochlear nonsensory cells. 
A
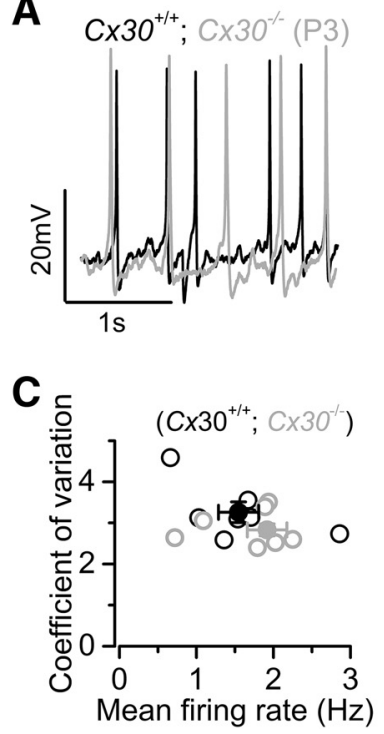

B

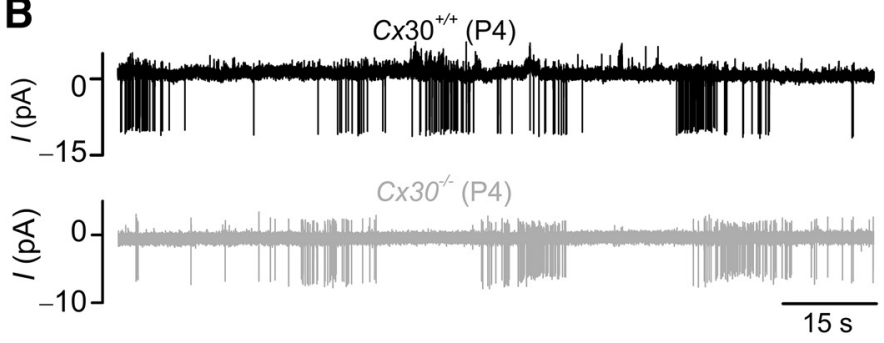

D

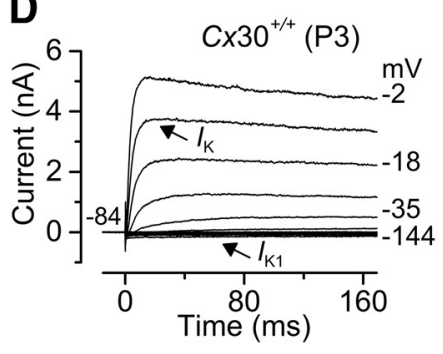

E

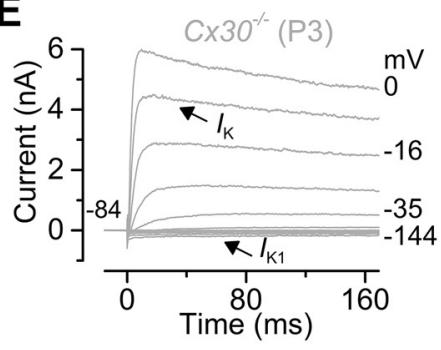

Figure 1. Connexins do not alter the biophysical properties of immature IHCs. $A$, Spontaneous APs recorded from IHCs under whole-cell current-clamp configuration from P3 $(x 30$ ( $-/-)$ mice and control littermates $(+/+)$. In this and the following figures, black represents control (wild-type or heterozygous) and gray represents mutant or knock-out mice. $\boldsymbol{B}$, APs in cell-attached voltage clamp recorded from a P4 control (top) and P4 (X30(-/-) (bottom) IHC. C, Coefficient of variation from each IHC against their firing rate. Open symbols represent data from single IHCs. Closed symbols represent averages. D, E, Potassium currents elicited from P3 IHCs by applying depolarizing voltage steps in $10 \mathrm{mV}$ nominal increments from $-144 \mathrm{mV}$, starting from the holding potential of $-84 \mathrm{mV}$. Recordings were performed at body temperature.

Table 1. Properties of immature and mature IHCs from Cx30 and Cx26 knock-out mice ${ }^{a}$

\begin{tabular}{|c|c|c|c|c|c|c|c|}
\hline & \multicolumn{2}{|l|}{$\begin{array}{l}\text { Immature } \\
\text { Cx30 K0(P3) }\end{array}$} & \multicolumn{2}{|l|}{$\begin{array}{l}\text { Adult } \\
\text { Cx30 K0 (P16-P18) }\end{array}$} & \multicolumn{2}{|l|}{$\mathrm{C} \times 26^{\text {Sox10-Cre }}(\mathrm{P} 25)$} & \multirow{2}{*}{$\begin{array}{l}\mathrm{C} \times 30 \Delta / \Delta(\mathrm{P} 25) \\
\Delta / \Delta\end{array}$} \\
\hline & $+1+$ & $-1-$ & $+1+$ & $-1-$ & $+1+$ & $-1-$ & \\
\hline Resting potential (mV) & $-57.7 \pm 1.6(4)$ & $-58.5 \pm 0.5(4)$ & $-74.4 \pm 1.1(11)$ & $-69.3 \pm 1.2(11)$ & $-69.2 \pm 1.9(3)$ & $-73.5 \pm 1.4(8)$ & $-73.5 \pm 2.6(5)$ \\
\hline$I_{\mathrm{K} 1}$ at $-124 \mathrm{mV}(\mathrm{pA})$ & $-120 \pm 31(4)$ & $-126 \pm 25(9)$ & - & $-121 \pm 13(9)$ & - & $?$ & - \\
\hline$I_{\mathrm{K}}$ at $0 \mathrm{mV}(\mathrm{nA})$ & $4.5 \pm 0.3(5)$ & $3.9 \pm 0.2(9)$ & $12.8 \pm 1.5(10)$ & $10.4 \pm 0.8(9)$ & $13.1 \pm 1.5(3)$ & $10.7 \pm 1.0(8)$ & $13.5 \pm 0.4(6)$ \\
\hline$I_{\mathrm{K}, \mathrm{f}}$ at $-25 \mathrm{mV}(\mathrm{nA})$ & - & - & $1.8 \pm 0.3(10)$ & - & $3.7 \pm 0.2(3)$ & $1.4 \pm 0.2(8)$ & $2.8 \pm 0.2(6)$ \\
\hline$I_{\mathrm{K}, \mathrm{n}}^{\mathrm{n}}$ at $-124 \mathrm{mV}(\mathrm{pA})$ & - & - & $98 \pm 67(7)$ & - & $302 \pm 17(3)$ & $144 \pm 17(8)$ & $349 \pm 26(5)$ \\
\hline
\end{tabular}

${ }^{a}$ Data are mean \pm SEM. Values in parentheses are number of hair cells. $I_{\mathrm{K} 1}$, Inward rectifier $\mathrm{K}^{+}$current (Marcotti et al., 1999); $I_{\mathrm{K}}$, delayed rectifier $\mathrm{K}^{+}$current (Marcotti et al., 2003$) ; I_{\mathrm{K}, \mathrm{n}}$, negatively activated $\mathrm{K}^{+}$current carried by $\mathrm{KCNQ4}$ channels (Marcotti et al., 2003); $I_{\mathrm{K}, \mathrm{f}}, \mathrm{Ca}^{2+}$-activated $\mathrm{K}^{+}$current (Kros et al., 1998); - , not present; ?, size of $I_{\mathrm{K} 1}$ was difficult to quantify because, if present, it was masked by $I_{\mathrm{K}, \mathrm{n}}$.

\section{IHCs from $C x 30(-/-)$ mice fail to acquire adult-type membrane currents}

Because genetic ablation of connexins from the cochlear sensory epithelium does not alter the basolateral membrane properties of IHCs during the first postnatal week (Fig. 1; Table 1), we set out to determine whether it impacts on the progression of IHC development. To address this question, we measured the biophysical properties of posthearing IHCs. Hair cell membrane capacitance $\left(C_{\mathrm{m}}\right)$, which gives an estimate of the cell's surface area, showed that control IHCs $(10.40 \pm 0.25 \mathrm{pF}, n=14$, P18P25) where significantly bigger than those from $C \times 30(-/-)$ littermates (9.06 $\pm 0.30 \mathrm{pF}, n=17, \mathrm{P} 18-\mathrm{P} 24, p<0.005)$, indicating that the absence of $\mathrm{Cx} 30$ impaired the normal growth of IHCs. We also recorded the total outward $\mathrm{K}^{+}$current in mature IHCs by applying a series of depolarizing voltage steps in 10 $\mathrm{mV}$ increments from $-144 \mathrm{mV}$ (holding potential was $-84 \mathrm{mV}$ ). The mature-type currents $I_{\mathrm{K}, \mathrm{f}}$ (Kros et al., 1998) and $I_{\mathrm{K}, \mathrm{n}}$ (Marcotti et al., 2003) were both present in P16-P18 control IHCs (Fig. $3 A)$, but undetectable in cells from aged-matched $C \times 30(-/-)$ littermates (Fig. 3B; Table 1). In the latter, IHCs also retained the inward rectifier $\mathrm{K}^{+}$current $I_{\mathrm{K} 1}$, which is characteristic of an immature electrophysiological phenotype (Marcotti et al., 1999). Consistent with this conclusion, IHCs from $C \times 30(-/-)$ mice had a resting membrane potential $\left(V_{\mathrm{m}}\right)$ significantly more depo- larized than that measured in cells from control littermates $(p<$ 0.01 ; Table 1), responded to depolarizing current injections with much larger voltage responses (Fig. $3 C, D$ ) and retained some ability to generate slow $\mathrm{Ca}^{2+}$ APs at the response onset (Fig. 3E).

We also found that IHCs from mature $C \times 30(-/-)$ mice expressed SK2 channels (Fig. 4A) and showed IPSCs (Fig. 4B), which are driven by spontaneous release of ACh from the efferent fibers. This ACh-activated current, which is mediated by $\mathrm{Ca}^{2+}$ entering hair cells through a9a10-nAChRs and activates SK2 channels, is normally only present in immature IHCs (Glowatzki and Fuchs, 2000; Marcotti et al., 2004), at a time when efferent endings make transient axosomatic synaptic contact with these cells (Pujol et al., 1998). These findings further support the evidence that IHCs from $C \times 30(-/-)$ mice retain an immature phenotype.

\section{The biophysical properties of ribbon synapses and vesicle pool size is affected in IHCs from $C x 30(-/-)$ mice}

We then tested whether the absence of connexins in nonsensory cells also affected ribbon synapse function in IHCs, which is crucial for sound encoding. Exocytosis was estimated by measuring increases in cell membrane capacitance $\left(\Delta C_{\mathrm{m}}\right)$ following $50 \mathrm{~ms}$ depolarizing voltage steps. We found that, in IHCs from adult CX30(-/-) mice, the maximal size of the $\mathrm{Ca}^{2+}$ current $\left(I_{\mathrm{Ca}}\right)$ was 
A

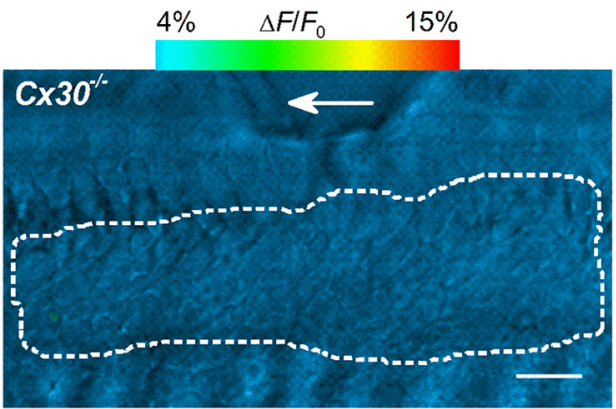

C
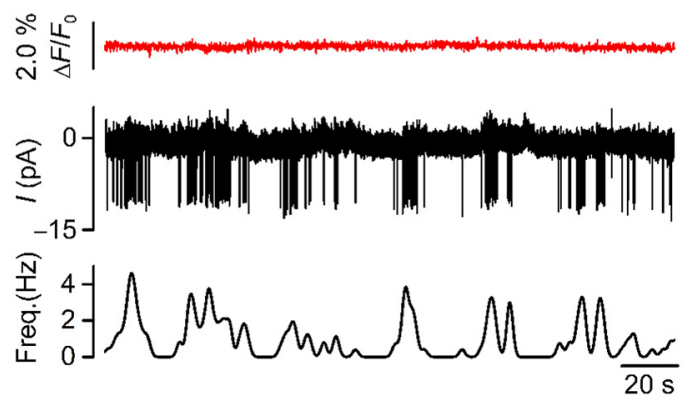

B

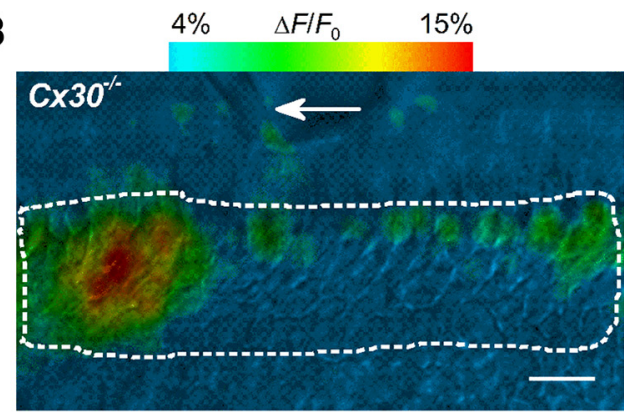

D

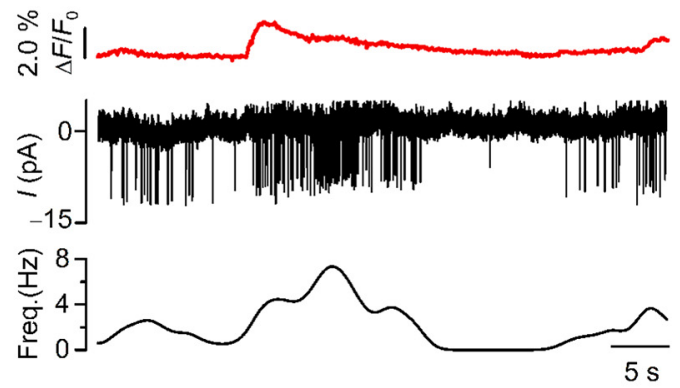

Figure 2. Spontaneous APs in IHCs are present in the absence of $\mathrm{Ca}^{2+}$ signals from nonsensory cells in $\mathrm{C} \times 30(-/-)$ mice. $A, B$, Representative false-color images of Fluo-4 fluorescence changes $\left(\Delta F / F_{0}\right)$, encoded as shown by the color scale bar (top) and obtained as maximal projection rendering of all frames recorded in $200 \mathrm{~s}(10 \mathrm{frame} / \mathrm{s})$. The images show a small part of the GER in the proximity of the patched IHC (arrows) from P6 $C \times 30(-/-)$ mice. Note the absence $(\boldsymbol{A})$ or some residual $(\boldsymbol{B}) \mathrm{Ca}^{2+}$ signals from nonsensory cells in the GER. IHCs were patched from the pillar side to prevent damage to the GER. Scale bar, $10 \mu \mathrm{m} . C, D$, Simultaneous recording of $\mathrm{Ca}^{2+}$ transients in the nonsensory cells present in the $G E R$ using fluorescence imaging $\left(\Delta F / F_{0}\right.$; see Materials and Methods) from white ROI delineated by the dashed white line in panel $\boldsymbol{A}$ and $\boldsymbol{B}$, respectively. Middle panels, IHC firing activity using cell-attached patch clamp. Bottom panels, Changes in AP frequency during the recordings. APs were present even when $\mathrm{Ca}^{2+}$ transients in the GER were absent $\left(\boldsymbol{A} ; \boldsymbol{C}\right.$, top), but their frequency increases during the residual $\mathrm{Ca}^{2+}$ transients in $C \times 30(-/-)$ mice $(\boldsymbol{B} ; \boldsymbol{D}$, top). Recordings were performed at body temperature.

A

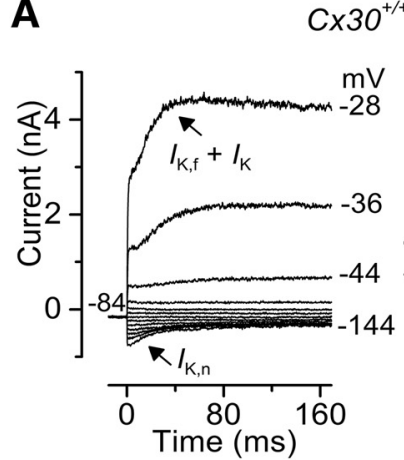

C

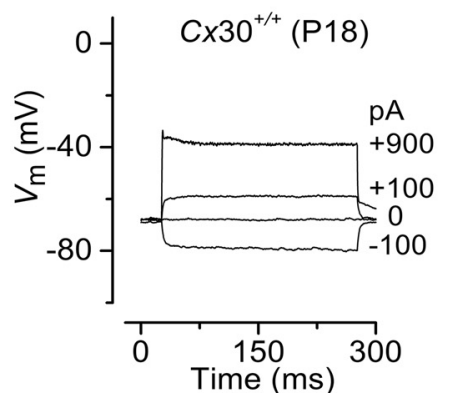

B

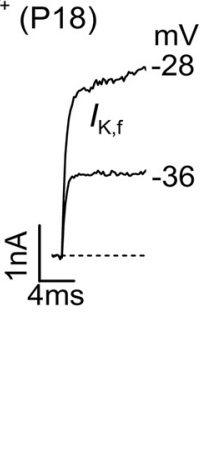

D

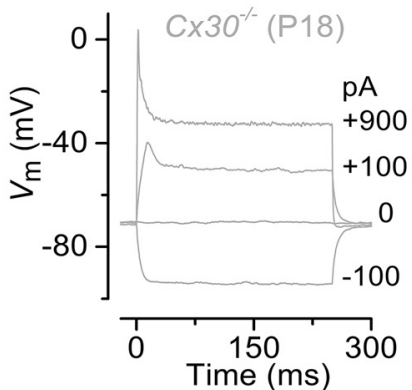

$\mathrm{C} \times 30^{-/}(\mathrm{P} 18)$

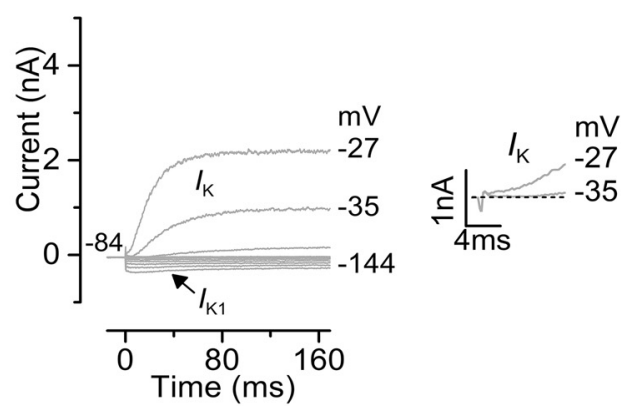

E

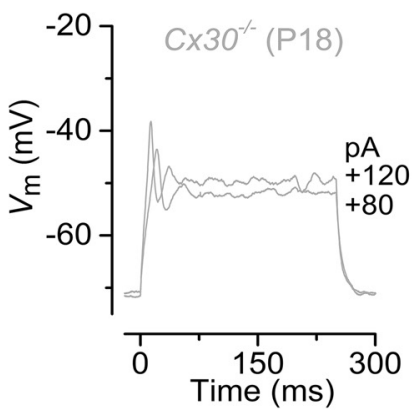

Figure 3. Current and voltage responses recorded from IHCs of $C \times 30(-/-)$ mice. $A, B$, Potassium currents recorded from P18 IHCs of wild-type $(\boldsymbol{A})$ and littermate $C \times 30(-/-)(B)$ mice using depolarizing voltage steps in $10 \mathrm{mV}$ nominal increments from the holding potential of $-84 \mathrm{mV}$ to the various test potentials shown by some of the traces. The adult-type currents $\left(I_{K, f}\right.$ and $\left.I_{K, n}\right)$ were only present in $\mathrm{IHCs}$ from wild-type mice $(A)$. IHCs from $\mathrm{CX} 3 \mathrm{O}(-/-)$ mice retained the currents characteristic of immature cells $\left(I_{\mathrm{K}, \mathrm{S}}\right.$ and $\left.I_{\mathrm{K} 1}\right)$. The presence of the rapidly activating $I_{\mathrm{K}, \mathrm{f}}$ in control IHCs is evident when comparing the activation time course of the total outward currents shown in the insets on an expanded time scale. $C-\boldsymbol{E}$, Voltage responses elicited by applying hyperpolarizing and depolarizing current injections to control $(\boldsymbol{C})$ and $C \times 30(-/-)$ adult IHCS $(\boldsymbol{D}, \boldsymbol{E})$ from their respective membrane potentials. In some IHCs, depolarizing current injections caused slow APs at the onset of responses. Recordings were performed at room temperature. 

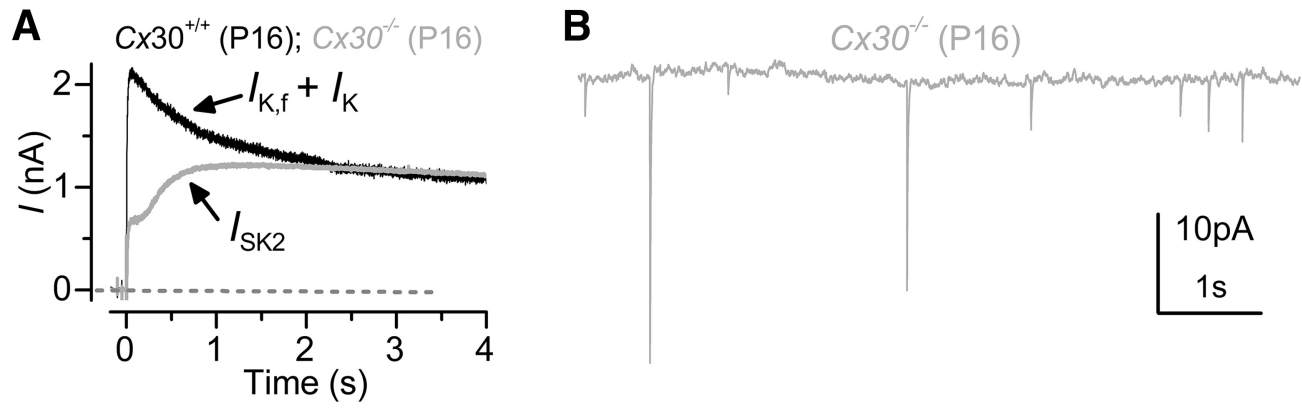

Figure 4. Efferent activity is still present in mature $\mathrm{C} 30(-/-) \mathrm{IHC}$. $A$, Outward currents obtained by using a $4 \mathrm{~s}$ depolarizing step to $0 \mathrm{mV}$ from the holding potential of $-84 \mathrm{mV}$ in control and Cx30(-/-) P16 IHCs (Marcotti et al., 2004). Although the SK2 current $\left(I_{\text {SK2 }}\right)$ is normally downregulated after the onset of hearing (Glowatzki and Fuchs, 2000), it was still expressed in mature CX30(-/-) IHCs. B, Spontaneous IPSCs recorded from a P16 CX30(-/-) IHC indicate that these IHCs retain the efferent endings that normally make only transient axosomatic synaptic contacts with IHCs during immature stages (Simmons et al., 1996; Katz et al., 2004). Recordings were performed at body temperature.

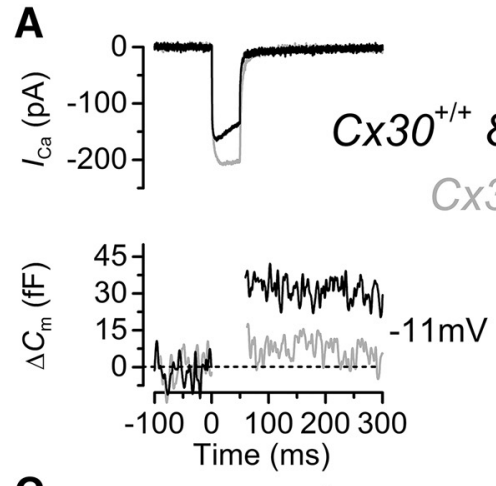

C

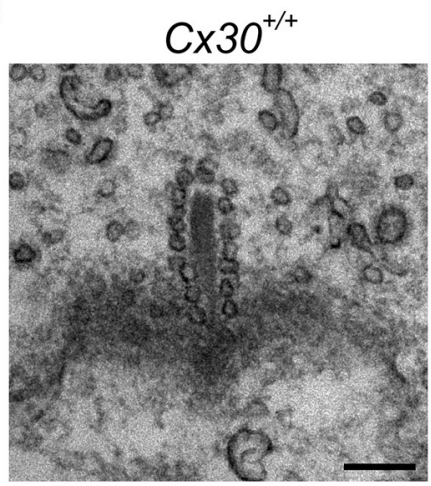

E

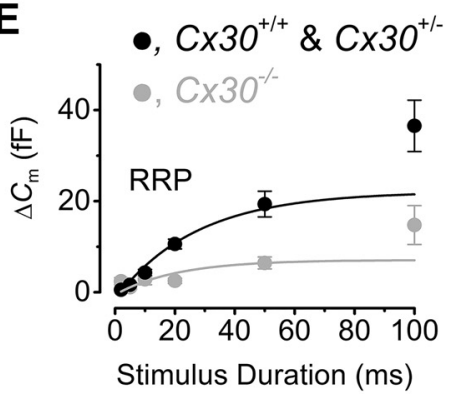

B

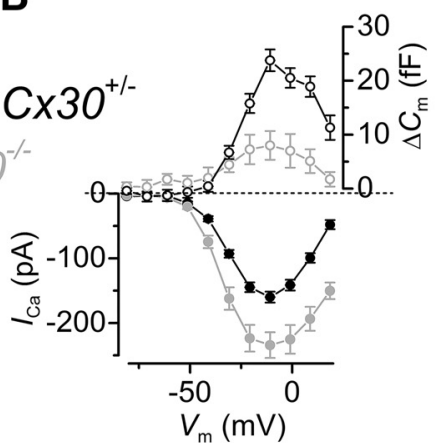

D

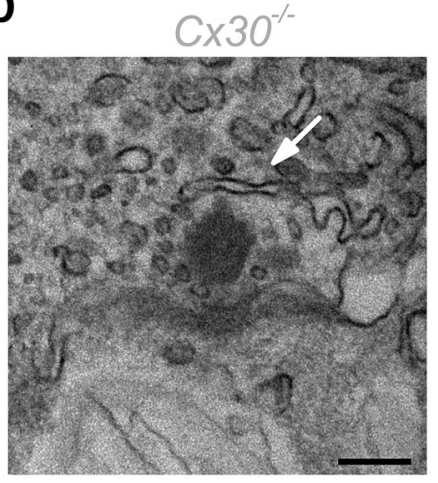

$\mathbf{F}$

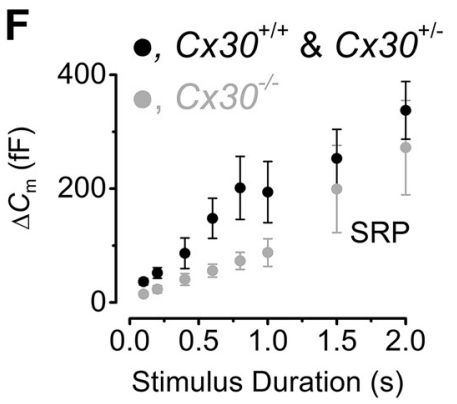

Figure 5. Exocytosis and ribbon morphology in $C \times 30(-/-) \mathrm{IHC} . \boldsymbol{A}, I_{\mathrm{Ca}}$ and corresponding $\Delta C_{\mathrm{m}}$ recorded from adult control and $\mathrm{C} \times 30(-/-) \mathrm{IHCs}$ obtained in response to $50 \mathrm{~ms}$ voltage steps, in $10 \mathrm{mV}$ increments, from $-81 \mathrm{mV}$. For clarity, only maximal responses at $-11 \mathrm{mV}$ are shown. $\boldsymbol{B}$, Average peak $I_{\mathrm{Ca}}$ (bottom) and $\Delta C_{\mathrm{m}}$ (top) curve from control (P17-P25, $\left.n=15\right)$ and Cx30(-/-) (P18-P24, $n=5)$ IHCS. C, D, Typical cross-sectional profiles of synaptic ribbons obtained from a control $(\boldsymbol{C})$ and a Cx30(-/-) (D) IHC. Some of the synaptic vesicles are missing around the ribbon of the $(x 30(-/-)$ IHC (arrow). Scale bar, 200 $\mathrm{nm} . \boldsymbol{E}, \boldsymbol{F}$, Average $\Delta C_{\mathrm{m}}$ from 12 control and $14(x 30(-/-) \mathrm{IHC}$ in response to voltage steps from $2 \mathrm{~ms}$ to $2 \mathrm{~s}$ (to $\sim-11 \mathrm{mV}$ ) showing the RRP $(\boldsymbol{E})$ and $\operatorname{SRP}(\boldsymbol{F})$. $\boldsymbol{E}$, The points at $100 \mathrm{~ms}$ represent the recruitment of the SRP. Recordings were performed at body temperature.

significantly larger $(p<0.001)$ than that of control cells (Fig. 5 A, $B$; Control IHCs $159.9 \pm 8.4 \mathrm{pA}, n=15, \mathrm{P} 17-\mathrm{P} 25$; Cx30(-/-) IHCs $234.1 \pm 19.8 \mathrm{pA}, n=5$, P18-P24), but similar to that normally measured in immature IHCs from wildtype mice (Johnson et al., 2010). Despite the larger $I_{\mathrm{Ca}}$, the corresponding $\Delta C_{\mathrm{m}}$ was significantly reduced in $C \times 30(-/-)$ mice (Fig. 5A, B; Control IHCs $23.8 \pm 2.0$ pF, $n=15 ; C x 30(-/-)$ IHCs $8.0 \pm 2.7 \mathrm{pF}$, $n=5, p<0.001)$, which is an indication of a reduced number of synaptic vesicles fusing to the plasma membrane. As such, the $\mathrm{Ca}^{2+}$ efficiency of exocytosis, which was measured by normalizing $\Delta C_{\mathrm{m}}$ to the peak $I_{\mathrm{Ca}}\left(\mathrm{fF} \mathrm{pA}^{-1}\right)$ was found to be significantly reduced in $C \times 30(-/-)$ IHCs $(0.034 \pm 0.022, n=5)$ compared with control cells $(0.150 \pm 0.046, n=15$, $p<0.0001)$, but similar to that obtained in prehearing IHCs $(0.053 \pm 0.011, n=$ 7 , P7). The reduced exocytosis in CX30(-/-) IHCs was confirmed by transmission electron microscopy, which showed significantly $(p<0.001)$ fewer vesicles tethered to the ribbon synapses of IHCs from $C \times 30(-/-)$ mice $(7 \pm 1, n=$ 10; Fig. $5 D)$ compared with control cells $(13 \pm 1, n=11$; Fig. $5 C)$. Moreover, the synaptic ribbons of control IHCs exhibited the characteristic ellipsoidal morphology previously described in mature mouse IHCs (Sobkowicz et al., 1982), whereas those in cells from $C \times 30(-/-)$ mice retained the more spherical shape typical of immature synapses (Sobkowicz et al., 1982).

We also investigated the two major components of the releasable vesicle pools (Fig. $5 E, F$ ) by measuring $\Delta C_{\mathrm{m}}$ in response to depolarizing voltage steps to $-11 \mathrm{mV}$ of increasing duration (from 2 $\mathrm{ms}$ to $2 \mathrm{~s}$ ). As previously shown, short stimuli (usually up to $50 \mathrm{~ms}$ ), applied to mouse IHCs in $1.3 \mathrm{~mm}$ extracellular $\mathrm{Ca}^{2+}$ 
and, at body temperature, reveal the number of vesicles docked at the active zones (readily releasable pool: RRP), whereas longer steps induce the release of vesicles from a secondarily releasable pool (SRP) (Johnson et al., 2010, 2013). We found that the size of the RRP in control IHCs $(22.1 \pm 2.7 \mathrm{fF}, n=12)$ was significantly larger than that obtained from CX30(-/- ) cells $(7.1 \pm 1.2 \mathrm{fF}, n=14, p<$ 0.0001 ; Fig. $5 E)$, in agreement with the above findings (Fig. 5A, B). However, the initial release rate of the RRP was similar between the two genotypes (control IHCs: $898 \pm 96 \mathrm{fF} / \mathrm{s}$ or $24275 \pm 2594$ vesicles/s, $n=12 ; C \times 30(-/-)$ IHCs: $1437 \pm 653$ $\mathrm{fF} / \mathrm{s}$ or $38840 \pm 17646$ vesicles/s, $n=14$, values obtained from fits to individual IHCs), indicating that only the number of available vesicles, not their biophysics of release, was affected in $C x 30(-/-)$ IHCs. In contrast, $\Delta C_{\mathrm{m}}$ responses induced by long-lasting voltage steps ( $200 \mathrm{~ms}$ to $2 \mathrm{~s}$ ) were found to be not significantly different (two-way ANOVA followed by the Bonferroni post test) between control and CX30(-/-) IHCs (Fig. $5 F$ ), showing that the number of vesicles located further away from the active zones was not significantly affected by the absence of connexins in the nonsensory cells of the cochlear sensory epithelium.

Overall, these results indicate that IHCs from $C \times 30(-/-)$ mice, in which the protein expression of Cx26 is also largely downregulated, retain a prehearing phenotype and, as such, would be unable to encode correctly incoming sound stimuli.

\section{Deletion of $\mathrm{Cx} 30$, but preservation of $\mathrm{Cx} 26$ expression in} $\mathrm{Cx} 30^{\Delta / \Delta}$ mice, is sufficient for near-normal IHC development Recent findings have shown that deletion of $C \times 30$ does not cause any measurable hearing loss in young adults of the $C \times 30^{\Delta / \Delta}$ mouse model. In these mice, $\mathrm{Cx} 30$ is absent, as in the $C \times 30(-/-)$ mice, but they retain a higher expression level of Cx26 ( 50\%) (Boulay et al., 2013) compared with the $C x 30(-/-)(\sim 10 \%)$ (Teubner et al., 2003). Therefore, the prediction was that the biophysical properties of IHCs from $C \times 30^{\Delta / \Delta}$ mice should be indistinguishable from those of wild-type control cells. Indeed, we found that adult (P25) IHCs from $C \times 30^{\Delta / \Delta}$ mice expressed both $I_{\mathrm{K}, \mathrm{f}}$ and $I_{\mathrm{K}, \mathrm{n}}$ (Fig. $6 \mathrm{~A}$ ) with peak currents matching that of control cells and, as such, much larger than that of $C \times 30(-/-)$ mice (Fig. 6B; see also Table 1). Voltage responses (Fig. 6C) and resting membrane potentials (Table 1 ) of $C \times 30^{\Delta / \Delta}$ IHCs were also similar to those measured in control cells (Fig. $3 C$ ). A possible conclusion is that the near-complete absence of $\mathrm{Cx} 26$ is likely to be responsible for the IHC defects observed in $C \times 30(-/-)$ mice (Figs. 3 ; 5). We tested this hypothesis by performing recordings from adult IHCs of $C \times 26^{\text {Sox10-Cre }}$ mice (Cx26 loxp/loxp $\times$ Sox10-Cre; see Materials and Methods; Fig. 7), in which Cx26 is not present in the sensory epithelium of the cochlea, whereas the normal expression of $\mathrm{Cx} 30$ is delayed, such that it only starts to be present in the GER during the second postnatal week and becomes normal from approximately P14 (Crispino et al., 2011). Adult IHCs from Cx26 $6^{\text {Sox10-Cre }}$ mice (P25) showed a current profile (Fig. $7 B, C)$ similar to that of normal cells (Fig. $7 A, C)$ but with a significantly reduced size of both $I_{\mathrm{K}, \mathrm{f}}(p<0.0001)$ and $I_{\mathrm{K}, \mathrm{n}}(p<$ 0.001 ) (Table 1). Voltage responses (Fig. $7 D, E$ ) were different between control and Cx26 $6^{\text {Sox10-Cre }}$ mature IHCs, reflecting the reduced expression of $I_{\mathrm{K}, \mathrm{f}}$ and $I_{\mathrm{K}, \mathrm{n}}$. Therefore, the expression of
Cx30 in Cx26 $6^{\text {Sox10-Cre }}$ mice during the second postnatal week, although reduced, is sufficient to trigger a partial maturation of the IHCs, indicating that both connexins contribute to the acquisition of normal hearing.

\section{Discussion}

Using near-physiological recording conditions, we have shown that, different from previous suggestions (Tritsch et al., 2007, 2010), ATP released from nonsensory cells of the immature mouse cochlea is not required for the generation of APs in IHCs. Our data from $C \times 30(-/-)$ mice show that immature IHCs exhibit spontaneous AP activity that is similar to that recorded in control cells and, as such, is independent from Cx26/Cx30 gapjunction channels or hemichannels. However, the presence of ATP-induced signaling in nonsensory cells increases the AP frequency in IHCs. We also found that a threshold level for the expression of both $\mathrm{Cx} 26$ and $\mathrm{Cx} 30$ is required for the acquisition of the mature sensory profile in IHCs and, as such, for the normal hearing.

\section{Contribution of $\mathrm{Cx} 26$ and $\mathrm{Cx} 30$ to the hearing phenotype}

$\mathrm{Cx} 26$ and $\mathrm{Cx} 30$ are the predominant connexins in the mammalian cochlea and the only isoforms expressed in the sensory epithelium (Jagger and Forge, 2015; Wingard and Zhao, 2015). These connexins have been shown to form extrajunctional hemichannels (Anselmi et al., 2008; Majumder et al., 2010) and also to coassemble to form homomeric or heteromeric gap junction channels between nonsensory cells (Forge et al., 2003; Martínez et al., 2009). This cell syncytium does not include the sensory IHCs or OHCs (e.g., Oesterle and Dallos, 1990; Jagger and Forge, 2006; Majumder et al., 2010), yet connexins have been shown to be crucial for hearing as deletion of Cx26 (e.g., Cohen-Salmon et al., 2002; Crispino et al., 2011) and mutation of $\mathrm{Cx} 26$ or $\mathrm{Cx} 30$ cause hearing loss in mice (Schütz et al., 2010, 2011) and humans (Wang et al., 2011; e.g., del Castillo and del Castillo, 2012). Deletion of Cx30 is normally associated with substantial downregulation of Cx26 expression in $C x 30(-/-)$ mice (Ortolano et al., 2008) as well as in DFNB1 patients (Lerer et al., 2001; Pallares-Ruiz et al., 2002; del Castillo et al., 2002; Rodriguez-Paris and Schrijver, 2009). The highly reduced expression of Cx26 in $C \times 30(-/-)$ mice occurs because the two genes expressing these proteins are only $50 \mathrm{~kb}$ apart, such that large deletions in the DFNB1 locus in humans or large insertions (lacZ or neo cassette) in mice cause downregulation in the expression of both Cx26 and Cx30 (Boulay et al., 2013). Overexpression of Cx30 by viral 
A

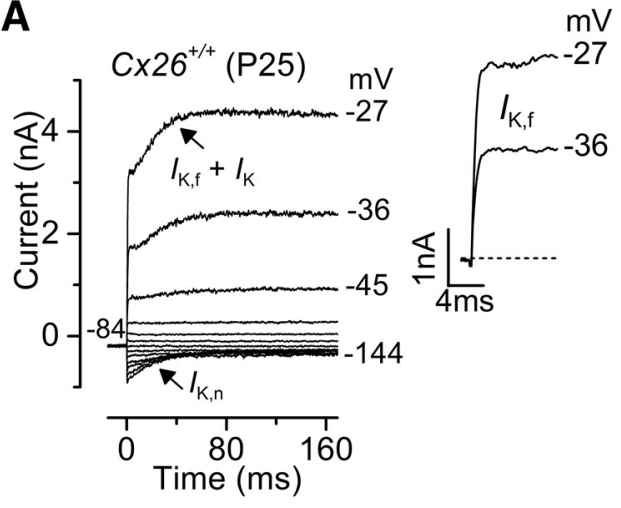

B

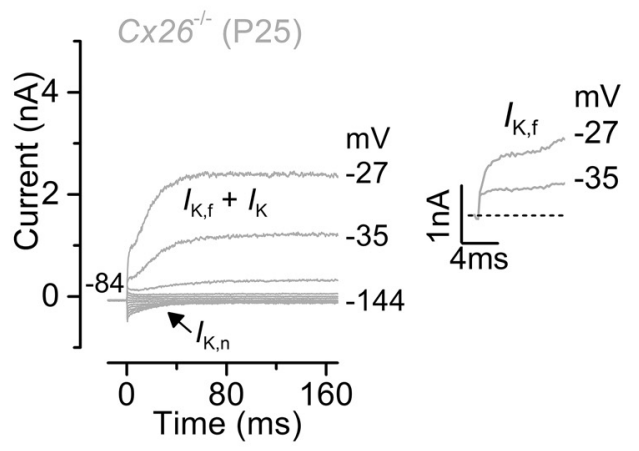

C

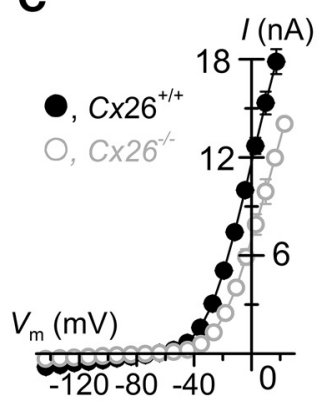

D

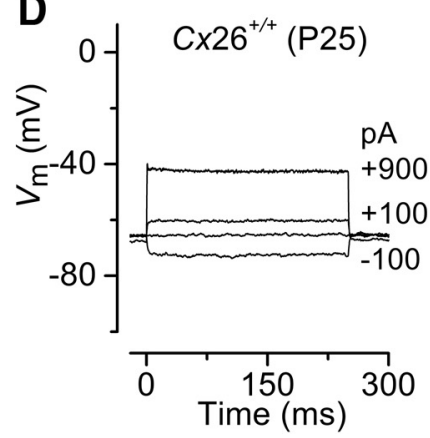

E

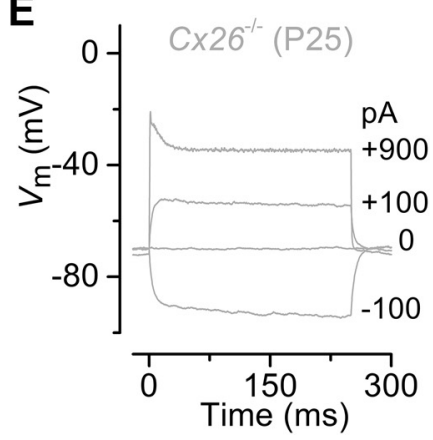

Figure 7. Current and voltage responses recorded from IHCS of $C \times 26^{\text {Sox } 10-C r e}$ mice. $\boldsymbol{A}, \boldsymbol{B}$, Potassium currents recorded from P25 IHCS of wild-type $(\boldsymbol{A})$ and littermate $C \times 26^{\text {Sox } 10-C r e}(\boldsymbol{B})$ mice using the same voltage protocol as described in Figure 3. Both the rapidly activating $I_{K, \mathrm{f}}$ and the negatively activated $I_{\mathrm{K}, \mathrm{n}}$ were present in the $\left(\times 26^{\text {Sox } 10 \text {-Cre }} I \mathrm{HC}\right.$, although reduced in size compared with the control cell. C, Current-voltage curves obtained as in Figure $6 B$ from IHCs of wild-type $\left(C \times 26^{+/+}: n=3, P 25\right)$ and $C \times 26^{\text {Sox } 10-C r e}\left(C \times 26^{-/-}: n=8, P 25\right)$ mice. D, E, Voltage responses elicited as described in Figure 3 from control $(\boldsymbol{D})$ and knock-out $(\boldsymbol{E})$ adult IHCs from the same cells shown in $\boldsymbol{A}$ and $\boldsymbol{B}$, respectively. Recordings were performed at room temperature.

transduction of $C \times 30(-/-)$ organotypic cultures restored Cx26 mRNA expression at levels similar to those in wild-type controls (Ortolano et al., 2008). On the other hand, viral transduction of $C \times 26^{\text {loxP/loxP }}$ cultures with a vector encoding the bacterial Cre recombinase reduced mRNA levels of both connexins (Ortolano et al., 2008). Normal hearing was restored in $C \times 30(-/-)$ when Cx26 was overexpressed (Ahmad et al., 2007), and preserved in $C \times 30^{\Delta / \Delta}$ mice where approximately half of the normal Cx26 was retained (Boulay et al., 2013). Together, these results indicate that the expression level of both connexin genes is closely interrelated.

Our results show that an absence of $\mathrm{Cx} 30$ in $C \times 30^{\Delta / \Delta}$ mice (with $\sim 50 \%$ of the normal Cx26), does not prevent the normal functional maturation of prehearing IHCs. By contrast, in Cx30(-/-) mice, which have no Cx30 and only $\sim 10 \%$ of residual Cx26, IHCs failed to achieve functional maturation and retained their prehearing biophysical and morphological configuration. In Cx26 $6^{\text {Sox10-Cre }}$ mice, in which Cx26 is not expressed in the sensory epithelium (Crispino et al., 2011), IHCs were able to develop, but only partially, indicating that the residual Cx30 expression in these mice was sufficient to promote some initial maturation. Therefore, IHC functional differentiation into mature sensory receptor is initiated provided that the expression of either connexin reaches a threshold level, which is likely to be $\sim 50 \%$ for $\mathrm{Cx} 26$ (as in $C \times 30^{\Delta / \Delta}$ mice). For $\mathrm{Cx} 30$ this level is not known, but because IHC maturation was initiated in Cx26 $6^{\text {Sox10-Cre }}$ mice, the threshold could be similar to that of Cx 26 . This functional interaction between Cx26 and Cx30, recently demonstrated in mouse models (Ortolano et al., 2008), has also been hypothesized in humans based on observations using superresolution microscopy (Liu et al., 2016).
In mature $C \times 30(-/-)$ mice, cochlear hair cells begin to degenerate and by 4 months of age cell loss is extensive (Teubner et al., 2003). This progressive degeneration has been previously linked to a complete absence of endocochlear potential in these CX30(-/-) mice (Teubner et al., 2003). However, a similar pattern of hair cell degeneration has been described in $\mathrm{Cx} 26^{\text {Sox10-Cre }}$ mice that show a residual $(40 \mathrm{mV})$ endocochlear potential (Crispino et al., 2011) and Beethoven mice that have a normal endocochlear potential (Marcotti et al., 2006). Therefore, the progressive loss of hair cells in $C \times 30(-/-)$ and $C \times 26^{\text {Sox10-Cre }}$ mice is likely to be a direct consequence of their inability to express adult-like currents, such as that carried by KCNQ4 channel $\left(I_{\mathrm{K}, \mathrm{n}}\right)$ (Kharkovets et al., 2006; Marcotti et al., 2006). Mutation in KCNQ4 channels has been shown to lead to progressive hearing loss in DFNA2 patients (Kubisch et al., 1999), suggesting that $I_{\mathrm{K}, \mathrm{n}}$ may be important for maintaining hair cell viability. The presence of immature IHCs and the reduced or absent endocochlear potential will, together, lead to hearing loss in mice and humans with mutations in connexins.

\section{Mechanisms underlying the interaction of cochlear nonsensory cells with IHCs}

The exact physiological role of connexin channels in nonsensory cells of the mammalian cochlea is still unclear. Current evidence indicates that $\mathrm{Cx} 26$ and $\mathrm{Cx} 30$ are crucial for maintaining the ionic and metabolic homeostasis of the inner ear and mediating intercellular signaling in the nonsensory epithelium (Mammano, 2013; Jagger and Forge, 2015; Wingard and Zhao, 2015). We now show that these connexins are also involved in the maturation of the biophysical and morphological properties of IHCs, which normally occurs at around the onset of hearing. It is known that 
Cx26 and Cx30 hemichannels in the nonsensory cells of the cochlea release ATP under physiological conditions (Anselmi et al., 2008; Rodriguez et al., 2012). The binding of extracellular ATP to G-protein coupled P2Y receptors on nonsensory cells activates the phospholipase-C dependent generation of $\mathrm{IP}_{3}$, which then binds to its receptors on the ER and promotes $\mathrm{Ca}^{2+}$ release, raising the cytosolic free $\left[\mathrm{Ca}^{2+}\right]$ and additional release of ATP (Beltramello et al., 2005; Piazza et al., 2007). This cascade of events enables the propagation of $\mathrm{Ca}^{2+}$ signals as regenerative and coordinated intercellular $\mathrm{Ca}^{2+}$ waves in cochlear nonsensory cells, sustained by ATP-induced ATP release (Beltramello et al., 2005; Piazza et al., 2007; Rodriguez et al., 2012; Ceriani et al., 2016b). Recent work has proposed that this ATP-dependent $\mathrm{Ca}^{2+}$ signaling is required to generate AP activity in IHCs (Tritsch et al., 2007, 2010; Wang et al., 2015). However, we now show that, in early postnatal $C \times 30(-/-)$ mice, which have a greatly reduced frequency of ATP-dependent $\mathrm{Ca}^{2+}$ activity in the nonsensory cells of the GER (Rodriguez et al., 2012), IHCs retain the ability to fire spontaneous APs (Fig. 1). However, the remaining $\mathrm{Ca}^{2+}$ waves originating in the nonsensory cells of Cx30(-/-) mice were able to increase the IHC firing activity (Fig. 2), supporting previous data showing that ATP released from nonsensory cells has mainly a modulatory role on APs in IHCs (Johnson et al., 2011). Despite the presence of AP activity, IHCs from $C \times 30(-/-)$ mice do not properly mature into sensory receptors.

A comparable failure in IHC maturation to that of Cx30(-/-) mice has previously been described in mutant or transgenic mice showing defects in the mechanoelectrical transducer current (tmc1: Marcotti et al., 2006; Kawashima et al., 2011; Eps8: Zampini et al., 2011; Myo6: Roux et al., 2009), which is believed to be directly implicated in the persistence of spontaneous AP activity in IHCs in vivo during the second postnatal week (Johnson et al., 2012). AP activity over this time window, just before the onset of hearing at P12, is used by IHCs to promote their own functional maturation in vivo (Johnson et al., 2013). Because connexin-dependent ATP-induced $\mathrm{Ca}^{2+}$ signaling activity from the GER can modulate the frequency of APs in immature IHCs (Fig. 2), it is conceivable that the reduced ATP release from nonsensory cells in $C \times 26^{\text {Sox } 10-C r e}$ and $C \times 30(-/-)$ mice is likely to alter the normal pattern of spontaneous AP activity in IHCs during the second postnatal week and, as such, IHC maturation. This is also supported by the evidence that the appearance of Cx30 during the second postnatal week in $C \times 26^{\text {Sox10-Cre }}$ mice, in which Cx26 is absent, is sufficient to promote a partial maturation of IHCs. The release of ATP from nonsensory cells could either affect the IHC firing activity directly, via the reduced activation of $\mathrm{P} 2$ receptors present in these cells (Housley et al., 2006; Tritsch et al., 2007; Johnson et al., 2011), or indirectly via the elevation of $\mathrm{K}^{+}$around the IHCs following the activation of ATP autoreceptors in neighboring nonsensory cells (Wang et al., 2015).

\section{References}

Ahmad S, Chen S, Sun J, Lin X (2003) Connexins 26 and 30 are coassembled to form gap junctions in the cochlea of mice. Biochem Biophys Res Commun 307:362-368. CrossRef Medline

Ahmad S, Tang W, Chang Q, Qu Y, Hibshman J, Li Y, Söhl G, Willecke K, Chen P, Lin X (2007) Restoration of connexin26 protein level in the cochlea completely rescues hearing in a mouse model of human connexin30-linked deafness. Proc Natl Acad Sci U S A 104:1337-1341. CrossRef Medline

Anselmi F, Hernandez VH, Crispino G, Seydel A, Ortolano S, Roper SD, Kessaris N, Richardson W, Rickheit G, Filippov MA, Monyer H, Mam- mano F (2008) ATP release through connexin hemichannels and gap junction transfer of second messengers propagate $\mathrm{Ca}^{2+}$ signals across the inner ear. Proc Natl Acad Sci U S A 105:18770-18775. CrossRef Medline

Beltramello M, Piazza V, Bukauskas FF, Pozzan T, Mammano F (2005) Impaired permeability to Ins $(1,4,5) \mathrm{P} 3$ in a mutant connexin underlies recessive hereditary deafness. Nat Cell Biol 7:63-69. CrossRef Medline

Beutner D, Moser T (2001) The presynaptic function of mouse cochlear inner hair cells during development of hearing. J Neurosci 21:4593-4599. Medline

Boulay AC, del Castillo FJ, Giraudet F, Hamard G, Giaume C, Petit C, Avan P, Cohen-Salmon M (2013) Hearing is normal without connexin30. J Neurosci 33:430-434. CrossRef Medline

Ceriani F, Ciubotaru CD, Bortolozzi M, Mammano F (2016a) Design and construction of a cost-effective spinning disk system for live imaging of inner ear tissue. In: Auditory and vestibular research: methods and protocols (Sokolowski B, ed). New York: Springer.

Ceriani F, Pozzan T, Mammano F (2016b) Critical role of ATP-induced ATP release for $\mathrm{Ca}^{2+}$ signaling in non-sensory cell networks of the developing cochlea. Proc Natl Acad Sci U S A 113:E7194-E7201. CrossRef Medline

Clause A, Kim G, Sonntag M, Weisz CJ, Vetter DE, Rúbsamen R, Kandler K (2014) The precise temporal pattern of prehearing spontaneous activity is necessary for tonotopic map refinement. Neuron 82:822-835. CrossRef Medline

Cohen-Salmon M, Ott T, Michel V, Hardelin JP, Perfettini I, Eybalin M, Wu T, Marcus DC, Wangemann P, Willecke K, Petit C (2002) Targeted ablation of connexin26 in the inner ear epithelial gap junction network causes hearing impairment and cell death. Curr Biol 12:1106-1111. CrossRef Medline

Crispino G, Di Pasquale G, Scimemi P, Rodriguez L, Galindo Ramirez F, De Siati RD, Santarelli RM, Arslan E, Bortolozzi M, Chiorini JA, Mammano F (2011) BAAV mediated GJB2 gene transfer restores gap junction coupling in cochlear organotypic cultures from deaf Cx26Sox10Cre mice. PLoS One 6:e23279. CrossRef Medline

Cunningham JP, Gilja V, Ryu SI, Shenoy KV (2009) Methods for estimating neural firing rates, and their application to brain-machine interfaces. Neural Netw 22:1235-1246. CrossRef Medline

del Castillo FJ, del Castillo I (2012) Genetics of isolated auditory neuropathies. Front Biosci (Landmark Ed) 17:1251-1265. CrossRef Medline

del Castillo I, Villamar M, Moreno-Pelayo MA, del Castillo FJ, Alvarez A, Tellería D, Menéndez I, Moreno F (2002) A deletion involving the connexin 30 gene in nonsyndromic hearing impairment. N Engl J Med 346: 243-249. CrossRef Medline

De Vuyst E, Decrock E, Cabooter L, Dubyak GR, Naus CC, Evans WH, Leybaert L (2006) Intracellular calcium changes trigger connexin 32 hemichannel opening. EMBO J 25:34-44. CrossRef Medline

Forge A, Becker D, Casalotti S, Edwards J, Marziano N, Nevill G (2003) Gap junctions in the inner ear: comparison of distribution patterns in different vertebrates and assessment of connexin composition in mammals. J Comp Neurol 467:207-231. CrossRef Medline

Fuchs PA (2005) Time and intensity coding at the hair cell's ribbon synapse. J Physiol 566:7-12. CrossRef Medline

Glowatzki E, Fuchs PA (2000) Cholinergic synaptic inhibition of inner hair cells in the neonatal mammalian cochlea. Science 288:2366-2368. CrossRef Medline

Goodenough DA, Paul DL (2009) Gap junctions. Cold Spring Harb Perspect Biol 1:a002576. CrossRef Medline

Housley GD, Marcotti W, Navaratnam D, Yamoah EN (2006) Hair cells: beyond the transducer. J Membr Biol 209:89-118. CrossRef Medline

Jagger DJ, Forge A (2006) Compartmentalized and signal-selective gap junctional coupling in the hearing cochlea. J Neurosci 26:1260-1268. CrossRef Medline

Jagger DJ, Forge A (2015) Connexins and gap junctions in the inner ear: it's not just about $\mathrm{K}^{+}$recycling. Cell Tissue Res 360:633-644. CrossRef Medline

Johnson SL, Forge A, Knipper M, Münkner S, Marcotti W (2008) Tonotopic variation in the calcium dependence of neurotransmitter release and vesicle pool replenishment at mammalian auditory ribbon synapses. J Neurosci 28:7670-7678. CrossRef Medline

Johnson SL, Franz C, Kuhn S, Furness DN, Rüttiger L, Münkner S, Rivolta MN, Seward EP, Herschman HR, Engel J, Knipper M, Marcotti W (2010) Synaptotagmin IV determines the linear calcium dependence of vesicle 
fusion at auditory ribbon synapses. Nat Neurosci 13:45-52. CrossRef Medline

Johnson SL, Eckrich T, Kuhn S, Zampini V, Franz C, Ranatunga KM, Roberts TP, Masetto S, Knipper M, Kros CJ, Marcotti W (2011) Positiondependent patterning of spontaneous action potentials in immature cochlear inner hair cells. Nat Neurosci 14:711-717. CrossRef Medline

Johnson SL, Kennedy HJ, Holley MC, Fettiplace R, Marcotti W (2012) The resting transducer current drives spontaneous activity in prehearing mammalian cochlear inner hair cells. J Neurosci 32:1047910483. CrossRef Medline

Johnson SL, Kuhn S, Franz C, Ingham N, Furness DN, Knipper M, Steel KP, Adelman JP, Holley MC, Marcotti W (2013) Presynaptic maturation in auditory hair cells requires a critical period of sensory-independent spiking activity. Proc Natl Acad Sci U S A 110:8720-8725. CrossRef Medline

Katz E, Elgoyhen AB, Gómez-Casati ME, Knipper M, Vetter DE, Fuchs PA, Glowatzki E (2004) Developmental regulation of nicotinic synapses on cochlear inner hair cells. J Neurosci 24:7814-7820. CrossRef Medline

Kawashima Y, Géléoc GS, Kurima K, Labay V, Lelli A, Asai Y, Makishima T, Wu DK, Della Santina CC, Holt JR, Griffith AJ (2011) Mechanotransduction in mouse inner ear hair cells requires transmembrane channellike genes. J Clin Invest 121:4796-4809. CrossRef Medline

Kelly JJ, Simek J, Laird DW (2015) Mechanisms linking connexin mutations to human diseases. Cell Tissue Res 360:701-721. CrossRef Medline

Kharkovets T, Dedek K, Maier H, Schweizer M, Khimich D, Nouvian R, Vardanyan V, Leuwer R, Moser T, Jentsch TJ (2006) Mice with altered KCNQ4 $\mathrm{K}^{+}$channels implicate sensory outer hair cells in human progressive deafness. EMBO J 25:642-652. CrossRef Medline

Kikuchi T, Kimura RS, Paul DL, Adams JC (1995) Gap junctions in the rat cochlea: immunohistochemical and ultrastructural analysis. Anat Embryol (Berl) 191:101-118. Medline

Kros CJ, Ruppersberg JP, Rüsch A (1998) Expression of a potassium current in inner hair cells during development of hearing in mice. Nature 394: 281-284. CrossRef Medline

Kubisch C, Schroeder BC, Friedrich T, Lütjohann B, El-Amraoui A, Marlin S, Petit C, Jentsch TJ (1999) KCNQ4, a novel potassium channel expressed in sensory outer hair cells, is mutated in dominant deafness. Cell 96:437446. CrossRef Medline

Kuhlbrodt K, Herbarth B, Sock E, Hermans-Borgmeyer I, Wegner M (1998) Sox10, a novel transcriptional modulator in glial cells. J Neurosci 18:237250. Medline

Lerer I, Sagi M, Ben-Neriah Z, Wang T, Levi H, Abeliovich D (2001) A deletion mutation in GJB6 cooperating with a GJB2 mutation in trans in non-syndromic deafness: a novel founder mutation in Ashkenazi Jews. Hum Mutat 18:460. CrossRef Medline

Leybaert L, Sanderson MJ (2012) Intercellular Ca(2+) waves: mechanisms and function. Physiol Rev 92:1359-1392. CrossRef Medline

Leybaert L, Braet K, Vandamme W, Cabooter L, Martin PE, Evans WH (2003) Connexin channels, connexin mimetic peptides and ATP release. Cell Commun Adhes 10:251-257. CrossRef Medline

Liu W, Edin F, Blom H, Magnusson P, Schrott-Fischer A, Glueckert R, Santi PA, Li H, Laurell G, Rask-Andersen H (2016) Super-resolution structured illumination fluorescence microscopy of the lateral wall of the cochlea: the Connexin26/30 proteins are separately expressed in man. Cell Tissue Res 365:13-27. CrossRef Medline

Mahendrasingam S, Macdonald JA, Furness DN (2011) Relative time course of degeneration of different cochlear structures in the $\mathrm{CD} / 1$ mouse model of accelerated aging. J Assoc Res Otolaryngol 12:437453. CrossRef Medline

Majumder P, Crispino G, Rodriguez L, Ciubotaru CD, Anselmi F, Piazza V, Bortolozzi M, Mammano F (2010) ATP-mediated cell-cell signaling in the organ of Corti: the role of connexin channels. Purinergic Signal 6:167187. CrossRef Medline

Mammano F (2013) ATP-dependent intercellular $\mathrm{Ca}^{2+}$ signaling in the developing cochlea: facts, fantasies and perspectives. Semin Cell Dev Biol 24:31-39. CrossRef Medline

Marcotti W, Géléoc GS, Lennan GW, Kros CJ (1999) Transient expression of an inwardly rectifying potassium conductance in developing inner and outer hair cells along the mouse cochlea. Pflugers Arch 439:113-122. CrossRef Medline

Marcotti W, Johnson SL, Holley MC, Kros CJ (2003) Developmental changes in the expression of potassium currents of embryonic, neonatal and mature mouse inner hair cells. J Physiol 548:383-400. CrossRef Medline
Marcotti W, Johnson SL, Kros CJ (2004) A transiently expressed SK current sustains and modulates action potential activity in immature mouse inner hair cells. J Physiol 557:613-633. CrossRef Medline

Marcotti W, Erven A, Johnson SL, Steel KP, Kros CJ (2006) Tmcl is necessary for normal functional maturation and survival of inner and outer hair cells in the mouse cochlea. J Physiol 574:677-698. CrossRef Medline

Martínez AD, Acuña R, Figueroa V, Maripillan J, Nicholson B (2009) Gapjunction channels dysfunction in deafness and hearing loss. Antioxid Redox Signal 11:309-322. CrossRef Medline

Matsuoka T, Ahlberg PE, Kessaris N, Iannarelli P, Dennehy U, Richardson WD, McMahon AP, Koentges G (2005) Neural crest origins of the neck and shoulder. Nature 436:347-355. CrossRef Medline

Monzack EL, Cunningham LL (2013) Lead roles for supporting actors: critical functions of inner ear supporting cells. Hear Res 303:20-29. CrossRef Medline

Oesterle EC, Dallos P (1990) Intracellular recordings from supporting cells in the guinea pig cochlea: DC potentials. J Neurophysiol 64:617-636. Medline

Ortolano S, Di Pasquale G, Crispino G, Anselmi F, Mammano F, Chiorini JA (2008) Coordinated control of connexin 26 and connexin 30 at the regulatory and functional level in the inner ear. Proc Natl Acad Sci U S A 105:18776-18781. CrossRef Medline

Pallares-Ruiz N, Blanchet P, Mondain M, Claustres M, Roux AF (2002) A large deletion including most of GJB6 in recessive non syndromic deafness: a digenic effect? Eur J Hum Genet 10:72-76. CrossRef Medline

Parekh AB (2011) Decoding cytosolic $\mathrm{Ca}^{2+}$ oscillations. Trends Biochem Sci 36:78-87. CrossRef Medline

Piazza V, Ciubotaru CD, Gale JE, Mammano F (2007) Purinergic signalling and intercellular $\mathrm{Ca}^{2+}$ wave propagation in the organ of Corti. Cell Calcium 41:77-86. CrossRef Medline

Pujol R, Lavigne-Rebillard M, Lenoir M (1998) Development of sensory and neural structures in the mammalian cochlea. In: Development of the auditory system (Rubel EW, Popper AN, Fay RR, eds), pp 146-192. New York: Springer.

Rodriguez L, Simeonato E, Scimemi P, Anselmi F, Calì B, Crispino G, Ciubotaru CD, Bortolozzi M, Ramirez FG, Majumder P, Arslan E, De Camilli P, Pozzan T, Mammano F (2012) Reduced phosphatidylinositol 4,5-bisphosphate synthesis impairs inner ear $\mathrm{Ca}^{2+}$ signaling and highfrequency hearing acquisition. Proc Natl Acad Sci U S A 109:1401314018. CrossRef Medline

Rodriguez-Paris J, Schrijver I (2009) The digenic hypothesis unraveled: the GJB6 del(GJB6-D13S1830) mutation causes allele-specific loss of GJB2 expression in cis. Biochem Biophys Res Commun 389:354-359. CrossRef Medline

Roux I, Hosie S, Johnson SL, Bahloul A, Cayet N, Nouaille S, Kros CJ, Petit C, Safieddine S (2009) Myosin VI is required for the proper maturation and function of inner hair cell ribbon synapses. Hum Mol Genet 18:46154628. CrossRef Medline

Schütz M, Scimemi P, Majumder P, De Siati RD, Crispino G, Rodriguez L, Bortolozzi M, Santarelli R, Seydel A, Sonntag S, Ingham N, Steel KP, Willecke K, Mammano F (2010) The human deafness-associated connexin 30 T5M mutation causes mild hearing loss and reduces biochemical coupling among cochlear non-sensory cells in knock-in mice. Hum Mol Genet 19:4759-4773. CrossRef Medline

Schütz M, Auth T, Gehrt A, Bosen F, Körber I, Strenzke N, Moser T, Willecke K (2011) The connexin26 S17F mouse mutant represents a model for the human hereditary keratitis-ichthyosis-deafness syndrome. Hum Mol Genet 20:28-39. CrossRef Medline

Simmons DD, Mansdorf NB, Kim JH (1996) Olivocochlear innervation of inner and outer hair cells during postnatal maturation: evidence for a waiting period. J Comp Neurol 370:551-562. CrossRef Medline

Sobkowicz HM, Rose JE, Scott GE, Slapnick SM (1982) Ribbon synapses in the developing intact and cultured organ of Corti in the mouse. J Neurosci 2:942-957. Medline

Teubner B, Michel V, Pesch J, Lautermann J, Cohen-Salmon M, Söhl G, Jahnke K, Winterhager E, Herberhold C, Hardelin JP, Petit C, Willecke K (2003) Connexin30 (Gjb6)-deficiency causes severe hearing impairment and lack of endocochlear potential. Hum Mol Genet 12:13-21. CrossRef Medline

Tritsch NX, Bergles DE (2010) Developmental regulation of spontaneous activity in the Mammalian cochlea. J Neurosci 30:1539-1550. CrossRef Medline 
Tritsch NX, Yi E, Gale JE, Glowatzki E, Bergles DE (2007) The origin of spontaneous activity in the developing auditory system. Nature 450: 50-55. CrossRef Medline

Uhlén P, Fritz N (2010) Biochemistry of calcium oscillations. Biochem Biophys Res Commun 396:28-32. CrossRef Medline

Wang HC, Lin CC, Cheung R, Zhang-Hooks Y, Agarwal A, Ellis-Davies G, Rock J, Bergles DE (2015) Spontaneous activity of cochlear hair cells triggered by fluid secretion mechanism in adjacent support cells. Cell 163:1348-1359. CrossRef Medline

Wang WH, Liu YF, Su CC, Su MC, Li SY, Yang JJ (2011) A novel missense mutation in the connexin 30 causes nonsyndromic hearing loss. PLoS One 6:e21473. CrossRef Medline

Wangemann P, Schacht J (1996) Homeostatic mechanisms in the cochlea. In: The cochlea (Dallos P, Popper A, Fay R, eds), pp 130-185. New York: Springer.

Watanabe K, Takeda K, Katori Y, Ikeda K, Oshima T, Yasumoto K, Saito H, Takasaka T, Shibahara S (2000) Expression of the Sox10 gene during mouse inner ear development. Brain Res Mol Brain Res 84:141-145. CrossRef Medline
Wingard JC, Zhao HB (2015) Cellular and deafness mechanisms underlying connexin mutation-induced hearing loss: a common hereditary deafness. Front Cell Neurosci 9:202. CrossRef Medline

Xu J, Nicholson BJ (2013) The role of connexins in ear and skin physiology: functional insights from disease-associated mutations. Biochim Biophys Acta 1828:167-178. CrossRef Medline

Zampini V, Rüttiger L, Johnson SL, Franz C, Furness DN, Waldhaus J, Xiong H, Hackney CM, Holley MC, Offenhauser N, Di Fiore PP, Knipper M, Masetto S, Marcotti W (2011) Eps8 regulates hair bundle length and functional maturation of mammalian auditory hair cells. PLoS Biol 9:e1001048. CrossRef Medline

Zdebik AA, Wangemann P, Jentsch TJ (2009) Potassium ion movement in the inner ear: insights from genetic disease and mouse models. Physiology (Bethesda) 24:307-316. CrossRef Medline

Zhu Y, Zong L, Mei L, Zhao HB (2015) Connexin26 gap junction mediates miRNA intercellular genetic communication in the cochlea and is required for inner ear development. Sci Rep 5:15647. CrossRef Medline 